\title{
PENERAPAN BIBLIOTHERAPY UNTUK MENURUNKAN TINGKAT PERILAKU AGRESI PADA REMAJA DI LPKA X
}

\author{
Fransiska Xaveria Aryani $^{1}$, Debora Basaria ${ }^{2}$ dan Santy Yanuar Pranawati ${ }^{3}$ \\ ${ }^{1}$ Program Studi Psikologi Profesi Jenjang Magister, Universitas Tarumanagara, Jakarta \\ Email: fransiskaxaveriaa@gmail.com \\ ${ }^{2}$ Fakultas Psikologi, Universitas Tarumanagara, Jakarta \\ Email: deborab@fpsi.untar.ac.id \\ ${ }^{3}$ Fakultas Psikologi, Universitas Tarumanagara, Jakarta \\ Email: santyyanuar@fpsi.untar.ac.id
}

\begin{abstract}
Adolescence is a period marked by the search for self-identity. Self-identity is a concept of self, an opportunity to achieve agreeable goals, values, and beliefs starting in adolescence. When adolescents experience problems in their search for identity - or when adolescents have limited opportunities - they are at risk of displaying behaviors with negative consequences. Adolescents with poor impulse control are more likely to display aggressive behavior and not think about their future. Aggression is defined as a physical or verbal behavior that hurts, threatens, or endangers other targeted individuals or objects. Bibliotherapy is an intervention that reduces the level of aggression in children and adolescents, therefore this study aims to determine the effectiveness of bibliotherapy in reducing the level of aggressive behavior among adolescents in X LPKA. Research and group intervention using bibliotherapy involved six participants. All participants are adolescents with a tendency towards aggression and were inmates at $X$ LPKA. This study uses one group pre-test post-test design. The intervention process was conducted throughout 6 sessions and each session lasted between 60-90 minutes. The results of the intervention shows that bibliotherapy is effective to reduce the level of aggressive behavior in adolescents in LPKAX. This can be seen from the results of the evaluation of interventions and pre-test and post-test comparison. In addition to changes in the level of aggressive behavior, changes are also seen in the proactivity of participants in the group.
\end{abstract}

Keywords: bibliotherapy, aggressive behavior, adolescents, juvenile detention center

\begin{abstract}
ABSTRAK
Masa remaja merupakan masa pencarian identitas diri. Identitas diri merupakan konsep mengenai diri, kesempatan mencapai tujuan, nilai, dan kepercayaan yang ingin disepakati mulai pada masa remaja. Ketika remaja mengalami masalah saat pencarian identitasnya - atau ketika remaja hanya memiliki kesempatan yang terbatas - remaja beresiko menampilkan perilaku dengan konsekuensi negatif. Remaja yang masih cenderung memiliki kontrol dorongan yang buruk dapat menyebabkan remaja tersebut kemungkinan besar untuk menampilkan perilaku agresi dan tidak memikirkan masa depannya. Agresi didefinisikan sebagai suatu perilaku yang dilakukan untuk menyakiti, mengancam, atau membahayakan individu lain atau objek-objek yang menjadi sasaran perilaku tersebut secara fisik atau verbal. Bibliotherapy merupakan salah satu jenis intervensi untuk menurunkan tingkat agresi pada anak dan remaja, sehingga penelitian ini bertujuan mengetahui efektifitas penerapan bibliotherapy untuk menurunkan tingkat perilaku agresi pada remaja di LPKA X. Penelitian dan intervensi kelompok dengan bibliotherapy ini melibatkan enam partisipan. Seluruh partisipan merupakan remaja dengan kecenderungan perilaku agresi dan berstatus sebagai anak didik lapas (andikpas) di LPKA X. Penelitian ini menggunakan one group pre-test post-test design. Proses intervensi dilaksanakan dalam 6 sesi dan setiap sesinya berlangsung antara 60-90 menit. Hasil intervensi dapat menunjukkan bahwa bibliotherapy efektif digunakan untuk menurunkan tingkat perilaku agresi pada remaja di LPKA X. Efektivitas bibliotherapy untuk menurunkan tingkat perilaku agresi pada remaja dapat dilihat dari hasil evaluasi intervensi dan perbandingan pre-test dan post-test. Selain perubahan pada tingkat perilaku agresinya, perubahan juga terlihat pada keaktifan partisipan dalam kelompok.
\end{abstract}

Kata Kunci: bibliotherapy, perilaku agresi, remaja, lembaga pembinaan khusus anak 


\section{PENDAHULUAN}

Masa remaja merupakan masa pencarian identitas diri. Menurut Erikson (dalam Papalia \& Feldman, 2012) identitas merupakan konsep mengenai diri, kesempatan mencapai tujuan, nilai, dan kepercayaan yang ingin disepakati mulai pada masa remaja. Perkembangan kognitif remaja sudah mulai mampu untuk membangun konstruk "teori tentang diri". Ketika remaja mengalami masalah saat pencarian identitas - atau ketika remaja hanya memiliki kesempatan yang terbatas remaja beresiko menampilkan perilaku dengan konsekuensi negatif seperti melakukan kriminalitas. Berdasarkan hubungan interpersonalnya, remaja cenderung lebih banyak menghabiskan waktu dengan teman sebaya dibandingkan dengan keluarganya. Kelompok teman sebaya dianggap dapat menjadi sumber afeksi, simpati, pemahaman, dan tuntunan moral; tempat memperoleh pengalaman; dan setting untuk meningkatkan kemandirian dan kebebasan dari orangtua (Papalia \& Feldman, 2012).

Pengaruh hubungan teman sebaya cenderung mencapai puncak pada usia 12 sampai 13 tahun dan akan semakin menurun hingga pada masa remaja akhir. Saat usia 13 atau 14 tahun, popularitas remaja semakin berhubungan dengan perilaku antisosial ringan seperti menggunakan obat terlarang, menonton tanpa membeli tiket, dan mendemonstrasikan kepada teman mengenai cara membebaskan diri dari peraturan orangtua. Perilaku antisosial tersebut juga dimungkinkan karena kecenderungan remaja yang semakin berani mencoba untuk mengambil resiko. Selain itu, pengaruh pola asuh yang tidak efektif, kegagalan di sekolah, pengaruh dari tetangga, dan status sosial-ekonomi yang rendah juga mempengaruhi perilaku antisosial pada remaja. Remaja cenderung masih memiliki kontrol dorongan yang buruk, sehingga remaja memiliki kemungkinan yang besar untuk menampilkan perilaku agresi dan tidak memikirkan masa depan (Papalia \& Feldman, 2012).

Agresi dapat didefinisikan sebagai suatu perilaku yang dilakukan untuk menyakiti, mengancam, atau membahayakan individu lain atau objek-objek yang menjadi sasaran perilaku tersebut secara fisik atau verbal (Buss, 1961). Perilaku remaja dapat semakin agresi ketika mengkonsumsi alkohol. Alkohol akan mempengaruhi individu yang mengkonsumsinya, sehingga individu dapat semakin menyerang walaupun hanya dengan sedikit gangguan (Baron \& Branscombe, 2012).

Berikut merupakan salah satu fenomena mengenai perilaku agresi yang dilakukan remaja akhirakhir ini. Dalam berita yang berjudul "Polisi Tangkap 2 Begal yang Tusuk Korban hingga Kritis di GDC Depok", diberitakan bahwa dua tersangka yang berinisial DW dan RRT masih berusia remaja yaitu 17 tahun dan 18 tahun. DW dan RRT melakukan tindak pencurian dengan kekerasan hingga korban sekarat di rumah sakit. Pelaku awalnya berpura-pura mencari alamat namun kemudian meminta handphone korban dan mengancamnya dengan senjata tajam. DW sebagai eksekutor akhirnya menusukkan senjata tajam ke bagian pinggang korban hingga sekarat karena korban menolak untuk menyerahkan handphonenya (Lova, 2018).

Berita tersebut juga menunjukkan adanya tahanan yang masih berusia anak atau remaja di Indonesia. Data dari Institute for Criminal Justice Reform atau ICJR (dalam Zuraya, 2017) menyatakan bahwa adanya peningkatan jumlah anak yang terdaftar di Unit Pelayanan Terpadu Ditjen PAS pada tahun 2017 dibandingkan tahun sebelumnya. Sampai bulan Juni 2017, tercatat bahwa terdapat sekitar 910 tahanan anak di Indonesia sedangkan jumlah tahanan anak hanya 697 anak pada awal tahun 2016. Data tersebut menunjukkan bahwa adanya kebutuhkan untuk memberikan pembinaan kepada anak yang bermasalah dibandingkan dengan memenjarakan anak-anak tersebut. 
Bibliotherapy merupakan salah satu jenis intervensi yang dapat digunakan untuk menurunkan tingkat perilaku agresi pada anak dan remaja. Anak yang agresi cenderung mengalami defisit pada kemampuan melihat perspektif, empati, dan tingkat penalaran moral yang rendah, sehingga anak hanya memiliki motivasi yang rendah untuk mengubah perilakunya. Bibliotherapy merupakan proses terapi yang menggunakan buku sebagai sarana bantuan, sehingga proses terapi dapat menjadi sarana perubahan bagi individu yang mengalami masalah. Bibliotherapy merupakan metode tidak langsung yang dapat membantu memberikan penanganan untuk anak dan remaja yang agresi. Dengan media literatur, bibliotherapy dapat membuat anak tidak terlalu defensif, dapat memahami, dan menumbuhkan insight positif. Literatur juga dapat menjadi sumber pemikiran yang membangun dan dasar untuk penyelesaian masalah yang kreatif (Shechtman, 2009). Dengan demikian, peneliti ingin melakukan intervensi kelompok pada beberapa anak didik lapas (andikpas) khususnya di LPKA X.

Permasalahan dalam penelitian ini "Apakah bibliotherapy dapat diterapkan untuk menurunkan tingkat perilaku agresi pada remaja di LPKA X? "Adapun tujuan penelitian ini bertujuan untuk menerapkan bibliotherapy sebagai upaya untuk menurunkan tingkat perilaku agresi pada remaja di LPKA X.

\section{METODE PENELITIAN Partisipan penelitian}

Penelitian dan proses intervensi kelompok dengan bibliotherapy ini melibatkan enam partisipan yang memiliki karakteristik, yaitu: (a) remaja yang berusia antara $14-18$ tahun, (b) dikeluhkan memiliki kecenderungan berperilaku agresi, (c) sedang mengikuti pendidikan kejar paket $\mathrm{C}$, dan (d) merupakan andikpas di LPKA X.

\section{Desain penelitian}

Desain penelitian ini adalah one group pre-test post-test design. Desain penelitian tersebut dilakukan dengan metode wawancara, tes grafis Draw A Person (DAP), dan pemberian skala ukur agresi untuk mengetahui perbandingan hasil sebelum dan sesudah mengikuti intervensi kelompok.

\section{Lokasi penelitian}

Penelitian ini dilakukan di LPKA X. Berdasarkan Undang-Undang No.11 tahun 2012 tentang Sistem Peradilan anak berimplikasi pada sistem Pemasyarakatan di Indonesia, khususnya dalam fungsi pemasyarakatan terkait perawatan pelayanan dan pembinaan Anak yang berhadapan dengan Hukum (ABH). Lembaga Pembinaan Khusus Anak (LPKA) merupakan lembaga baru yang menggantikan fungsi Lembaga Pemasyarakatan (Lapas) Anak sebagai tempat pelaksanaan pembinaan bagi anak.

\section{Instrumen penelitian}

Selain metode observasi dan wawancara, peneliti juga memberikan informal assessment, tes formal psikologi, dan skala ukur perilaku agresi. Peneliti menggunakan kasus Heinz Dilemma yang dasari teori dari Kholberg sebagai informal assessment untuk mengetahui tahap perkembangan moral setiap andikpas. Tes formal yang diberikan terdiri dari Culture Fair Intelligence Test (CFIT), Draw A Person (DAP), Wartegg Zeichen Test (WZT), Child Behavior Checklist (CBCL). Selain itu, peneliti juga meminta andikpas mengisi skala ukur agresi dari Buss dan Perry (1992). 


\section{Pengukuran}

Penelitian ini menggunakan skala ukur agresi yang dikembangkan oleh Buss dan Perry (1992). Skala agresi tersebut peneliti pinjam dari Bagian Riset dan Pengukuran Fakultas Psikologi Universitas Tarumanagara. Skala agresi dari Buss dan Perry (1992) terdiri dari 29 item yang mencangkup 4 dimensi agresi yaitu (a) physical aggression, merupakan perilaku agresi yang overt atau terlihat; (b) verbal aggression, merupakan kecenderungan individu untuk menyerang individu lain atau memberikan stimulus yang merugikan dan menyakitkan secara verbal melalui kata-kata atau penolakan; (c) anger, merupakan perasaan marah, kesal, sebal, dan bagaimana cara mengontrol hal tersebut; dan (d) hostility, merupakan perilaku agresi yang tergolong covert atau tidak terlihat (Buss \& Perry, 1992).

Skala agresi menggunakan skala likert. Skala ini memiliki butir dari sangat positif ke sangat negatif, dan sebaliknya. Subyek diminta untuk memberikan pendapat atas pernyataan-pernyataan tersebut dengan memberikan tanda silang $(\mathrm{X})$ pada salah satu alternatif jawaban yang dianggap paling sesuai dengan keadaan subyek. Skala agresi terdiri dari lima alternatif jawaban yaitu TP (Tidak Pernah), JR (Jarang), KK (Kadang-kadang), SR (Sering), dan SL (Selalu). Salah satu contoh item positif dalam skala ini yaitu "Jika diprovokasi berlebihan, saya akan memukul orang lain.", sedangkan contoh item negatif dalam skala ini yaitu "Saya dapat memikirkan bahwa tidak ada alasan untuk memukul seseorang."

\section{Prosedur penelitian}

Prosedur penelitian yang dilakukan terdiri dari proses screening atau pre-test berupa wawancara, infomal assessment, tes inteligensi (CFIT 3A), tes grafis (DAP dan WZT), CBCL, dan skala ukur agresi untuk mengetahui tingkat, perilaku agresi yang ditampilkan setiap partisipan. Setelah selesai sesi intervensi, peneliti akan kembali memberikan post-test dengan tes grafis (DAP) dan kembali memberikan kuesioner agresi untuk mengevaluasi penurunan perilaku agresi yang ditampilkan partisipan.

\section{Pelaksanaan intervensi}

Intervensi dengan bibliotherapy dilakukan selama 6 sesi yaitu pada tanggal 13 Desember 2018, 14 Desember 2018, 17 Desember 2018, 20 Desember 2018, 26 Desember 2018, dan 27 Desember 2018. Seluruh partisipan mengikuti setiap sesi intervensi dalam kelompok yang lengkap. Setiap sesi intervensi berlangsung selama -/+ 60-90 menit. Proses rincian intervensi didasarkan pada 4 tahapan yang perlu dilakukan dalam sesi bibliotherapy (Shechtman, 2009).

Tabel 1. Rancangan setiap sesi intervensi kelompok dengan bibliotherapy

\begin{tabular}{|c|c|c|}
\hline Sesi & Treatment & Tujuan \\
\hline $\begin{array}{c}1 \\
\text { Perkenalan } \\
\text { dan Warm-up }\end{array}$ & $\begin{array}{l}\text { - Perkenalan dan ice-breaking } \\
\text { - Tujuan individu } \\
\text { - Mengenal emosi } \\
\text { - Penutup }\end{array}$ & $\begin{array}{l}\text { - Menjelaskan tujuan dan gambaran proses terapi } \\
\text { - Partisipan mengenal group leader dan partisipan lain. } \\
\text { - Partisipan memahami peraturan kelompok dan } \\
\text { kontrak terapi. } \\
\text { - Partisipan menentukan dan memahami tujuan atau } \\
\text { harapannya mengikuti sesi terapi. } \\
\text { - Partisipan diajak untuk mengerti konsep emosi dan } \\
\text { jenisnya. }\end{array}$ \\
\hline $\begin{array}{c}2 \\
\text { Pembahasan } \\
\text { dengan konten } \\
\text { tentang } \\
\text { kemarahan }\end{array}$ & $\begin{array}{l}\text { - Introduction } \\
\text { - Literatur (cerita/ puisi/ film) } \\
\text { - Identifikasi emosi dan dinamika } \\
\text { perilaku } \\
\text { - Eksplorasi diri untuk menumbuhkan } \\
\text { insight } \\
\text { - Penutup }\end{array}$ & $\begin{array}{l}\text { - Partisipan diminta untuk mendengar cerita tentang } \\
\text { kemarahan yang berjudul "The Present". } \\
\text { - Partisipan memahami kondisi emosi pelaku agresi } \\
\text { dan dinamika perilakunya. } \\
\text { - Partisipan melakukan eksplorasi diri mengenai } \\
\text { peristiwa serupa yang pernah dialami dan memahami } \\
\text { dinamika perilakunya. }\end{array}$ \\
\hline
\end{tabular}




\begin{tabular}{|c|c|c|}
\hline $\begin{array}{l}3 \\
\text { Pembahasan } \\
\text { mengenai } \\
\text { penggunaan } \\
\text { kekuatan } \\
\text { dengan benar }\end{array}$ & $\begin{array}{l}\text { - Introduction } \\
\text { - Literatur (cerita/ puisi/ film) } \\
\text { - Identifikasi emosi dan dinamika } \\
\text { perilaku } \\
\text { - Eksplorasi diri untuk menumbuhkan } \\
\text { insight } \\
\text { - Penutup }\end{array}$ & $\begin{array}{l}\text { - Partisipan diminta untuk mendengar cerita tentang } \\
\text { agresi yang berjudul "The Bully". } \\
\text { - Partisipan memahami kondisi emosi pelaku agresi } \\
\text { dan dinamika perilakunya. } \\
\text { - Partisipan melakukan eksplorasi diri mengenai } \\
\text { peristiwa serupa yang pernah dialami dan memahami } \\
\text { dinamika perilakunya. }\end{array}$ \\
\hline $\begin{array}{c}\text { Pembahasan } \\
\text { mengenai } \\
\text { empati }\end{array}$ & $\begin{array}{l}\text { - Introduction } \\
\text { - Literatur (cerita/ puisi/ film) } \\
\text { - Identifikasi emosi dan dinamika } \\
\text { perilaku } \\
\text { - Eksplorasi diri untuk menumbuhkan } \\
\text { insight } \\
\text { - Penutup }\end{array}$ & $\begin{array}{l}\text { - Partisipan diminta untuk menonton film tentang } \\
\text { perilaku agresi pada remaja. Film merupakan film } \\
\text { pendek yang berjudul "The Big Bully". Partisipan } \\
\text { juga diminta menuliskan hal negatif yang diperoleh } \\
\text { korban dalam film tersebut. } \\
\text { - Partisipan memahami kondisi emosi korban agresi } \\
\text { dan dinamika perilakunya. } \\
\text { - Partisipan melakukan eksplorasi diri mengenai } \\
\text { peristiwa serupa yang pernah dialami dan memahami } \\
\text { dinamika perilakunya. }\end{array}$ \\
\hline $\begin{array}{c}5 \\
\text { Pembahasan } \\
\text { self-control }\end{array}$ & $\begin{array}{l}\text { - Introduction } \\
\text { - Literatur (cerita/ puisi/ film) } \\
\text { - Identifikasi dinamika perilaku } \\
\text { - Eksplorasi diri untuk menumbuhkan } \\
\text { insight } \\
\text { - Penutup }\end{array}$ & $\begin{array}{l}\text { - Partisipan diminta untuk melihat gambar dan } \\
\text { membuat cerita. } \\
\text { - Partisipan memikirkan kemungkinan dinamika } \\
\text { perilaku tokoh pada gambar. } \\
\text { - Partisipan melakukan eksplorasi diri mengenai } \\
\text { kemampuan partisipan untuk mengontrol diri ketika } \\
\text { berperilaku agresi. }\end{array}$ \\
\hline $\begin{array}{c}6 \\
\text { Termination }\end{array}$ & $\begin{array}{l}\text { - Introduction dan ice breaking } \\
\text { - Evaluasi tujuan partisipan } \\
\text { - Apresiasi dan feedback } \\
\text { - Diskusi dan kesimpulan } \\
\text { - Penutup }\end{array}$ & $\begin{array}{l}\text { - Mengevaluasi manfaat yang diperoleh partisipan dari } \\
\text { sesi terapi yang telah dilakukan. } \\
\text { - Partisipan diminta untuk saling memberikan apresiasi } \\
\text { dan feedback. } \\
\text { - Mendiskusikan dan menarik kesimpulan dari sesi } \\
\text { terapi. } \\
\text { - Partisipan memperoleh apresiasi dan perpisahan. }\end{array}$ \\
\hline
\end{tabular}

\section{HASIL DAN PEMBAHASAN}

\section{Hasil Draw A Person: Pre- \& Post.}

Secara umum, terdapat perubahan hasil pada gambar orang yang dibuat keenam partisipan saat pre-test dan post-test. Perubahan tersebut dapat terlihat dari tema gambar, tekanan garis, tipe garis, ukuran orang, kelengkapan orang, dan bagian yang ditekankan pada setiap gambar. Hal tersebut dapat mengindikasikan adanya perubahan kecenderungan perilaku agresi pada partisipan setelah mengikuti intervensi kelompok.

Pada $\mathrm{P}$, hasil post-test menunjukkan bahwa $\mathrm{P}$ mengalami penurunan kecenderungan perilaku agresi dan kemarahan, karena $\mathrm{P}$ lebih dapat mengontrol dirinya. $\mathrm{P}$ dapat menyalurkan dorongan ketidaksadarannya karena kecemasannya berkurang dan lebih percaya diri dibandingkan sebelumnya (mis, tipe garis discontinous pada pre-test $\rightarrow$ tipe garis continous pada post-test). $\mathrm{P}$ juga menjadi lebih dapat beradaptasi dan melakukan interaksi sosial dengan lingkungannya (mis, tidak ada gambar kaki pada pre-test $\rightarrow$ ada gambar kaki pada post-test).

Pada R, hasil post-test menunjukkan bahwa $\mathrm{R}$ lebih dapat menyalurkan dorongan ketidaksadarannya secara konstan karena mengalami penurunan tingkat kecemasan (mis, tipe garis discontinous pada pre-test $\rightarrow$ tipe garis continous pada post-test). $\mathrm{R}$ sebenarnya masih memiliki kecenderungan perilaku agresi dan perilaku bermusuhan, namun hal tersebut tidak terlalu ditekankan jika dibandingkan sebelum mengikuti intervensi kelompok. $\mathrm{R}$ juga lebih dapat memberikan kesan yang positif dengan tidak terobsesi untuk menampilkan kekuatan dirinya dan 
lebih dapat memposisikan dirinya di lingkungan (mis, gambar bahu orang yang besar dan kaku pada pre-test $\rightarrow$ gambar bahu lebih kecil pada post-test).

Pada A, hasil post-test menunjukkan adanya penurunan kecenderungan perilaku agresi atau keinginan A untuk berbuat perilaku delikuensi dengan senjata tajam (mis, tangan orang menggenggam senjata tajam pada pre-test $\rightarrow$ tidak menggenggam senjata tajam pada post-test). A lebih memiliki kesadaran untuk mengontrol dorongannya (terutama untuk melakukan perilaku agresi). A semakin dapat menyeimbangkan fungsi rasio dengan imajinasinya, serta semakin mau untuk bersosialisasi, berkomunikasi, dan terbuka untuk menunjukkan dirinya. A juga terkesan lebih dewasa karena merefleksikan kondisi masa lalunya (mis, orang memakai topeng pada pretest $\rightarrow$ orang tidak memakai topeng pada post-test).

Pada W, W sebenarnya masih memiliki kecenderungan untuk menampilkan perilaku agresi namun $\mathrm{W}$ berusaha untuk dapat mengontrol dirinya dan menggunakan fungsi emosinya. W juga terkesan lebih memiliki dewasa dan mengalai peningkatan kepercayaan diri. W berusaha tidak menggunakan kekuasaannya untuk berperilaku agresi karena $\mathrm{W}$ lebih dapat memposisikan dirinya (mis, gambar bahu bidang dan kaku pada pre-test $\rightarrow$ gambar bahu normal pada posttest). W juga mulai berani untuk berinteraksi dengan individu lain di sekitarnya (mis, tangan disembunyikan pada pre-test $\rightarrow$ satu lengan terbuka pada post-test).

Pada D, hasil post-test menunjukkan adanya penurunan kecenderung berperilaku agresi pada D. D sudah tidak terlihat akan menginternalisasi informasi dari lingkungan dan cenderung berperilaku agresi setelah D mengikuti proses intervensi kelompok. D lebih terkesan bersahabat, menyenangkan, positif, dan keinginan untuk menghibur (mis, penekanan pada wajah yang terkesan senang dan tersenyum pada post-test). Penurunan kecenderung perilaku negatif $\mathrm{D}$ juga dapat berdampak pada mobilitas dan peningkatan kemampuan adaptasi D dengan lingkungannya (mis, tidak ada tangan dan kaki pada pre-test $\rightarrow$ ada tangan pada post-test).

Pada RR, RR terlihat mengalami penurunan kecenderungan perilaku agresi fisik ataupun kecenderungan untuk membuat kekacauan dengan senjata tajam, walaupun masih adanya kecenderungan untuk melakukan agresi verbal (mis, tangan orang menggenggam senjata tajam pada pre-test $\rightarrow$ tidak menggenggam senjata tajam pada post-test). Hal tersebut dapat dikarenakan masih kurangnya tingkat kedewasaan RR (dibandingkan usianya saat ini). RR berusaha menyembunyikan dorongan untuk berperilaku agresinya. Penurunan perilaku agresi atau perilaku melawan RR dapat disebabkan karena RR mulai memiliki kepekaan emosional dan tidak hanya mengikuti dorongan agresinya.

\section{Hasil Skala Agresi: Pre- \& Post-}

Perubahan kecenderungan perilaku agresi pada keenam partisipan juga dapat dilihat dari perbandingan hasil pengukuran skala agresi saat pre-test dan post-test. Keenam partisipan terlihat mengalami perubahan nilai skala agresi (hingga perubahan golongan). Berikut merupakan penjabaran nilai hasil pre-test dan post-test dari setiap partisipan. Pertama, $\mathrm{P}$ mengalami penurunan nilai rata-rata perilaku agresi dari golongan sedang (dengan nilai 2.59) ke golongan rendah (menjadi 1.93). Kedua, hasil post-test $\mathrm{R}$ menunjukkan bahwa $\mathrm{R}$ mengalami sedikit perubahan (peningkatan sebesar 0.02) nilai rata-rata perilaku agresi dibandingkan hasil pre-test. Walaupun demikian, perilaku agresi $\mathrm{R}$ masih tergolong sedang berdasarkan normal kelompok. Ketiga, A menunjukkan perubahan perilaku agresi dari golongan tinggi (nilai 3.24) ke golongan sedang (nilai 2.57). Keempat, W mengalami penurunan tingkat skala perilaku agresi dari nilai 2.39 menjadi nilai 1.71 dan tergolong rendah berdasarkan norma kelompok. Kelima, 
skala agresi D terlihat mengalami perubahan nilai yaitu dari 2.85 menjadi 2.58 dan berada pada golongan sedang. Keenam, hasil pre-test RR menunjukkan bahwa perilaku agresinya dapat tergolong sedang dengan nilai 3.07 namun hasil post-test menunjukkan bahwa saat ini tingkat perilaku agresi RR sudah berada pada golongan rendah dengan nilai 2.35.

Tabel 2. Perbandingan hasil pre-test dan post-test skala ukur agresi

\begin{tabular}{ccc}
\hline Partisipan & Pre-test & Post-test \\
\hline $\mathbf{P}$ & 2.59 (Sedang) & 1.93 (Rendah) \\
$\mathbf{R}$ & 2.54 (Sedang) & 2.56 (Sedang) \\
$\mathbf{A}$ & 3.24 (Tinggi) & 2.57 (Sedang) \\
$\mathbf{W}$ & 2.39 (Rendah) & 1.71 (Rendah) \\
$\mathbf{D}$ & 2.85 (Sedang) & 2.58 (Sedang) \\
$\mathbf{R R}$ & 3.07 (Sedang) & 2.35 (Rendah) \\
\hline
\end{tabular}

Bibliotherapy sangat membantu berbagai bidang profesi untuk dapat membantu mengatasi masalah perilaku agresi pada berbagai kelompok usia dan populasi (Shechtman, 2009). Hasil penelitian ini sejalan dengan hasil penelitian dari Newman (2015) yang menunjukkan bahwa seluruh partisipan mengalami penurunan tingkat perilaku agresi dengan penanganan bibliotherapy. Partisipan yang memperoleh penanganan juga mengalami peningkatan empati, semakin bertumbuhkan wawasan, dan perubahan terapeutik dibandingkan partisipan yang hanya memperoleh konseling. Perubahan dalam penelitian ini juga terlihat pada penelitian dari Shechtman (2006) mengenai kontribusi bibliotherapy sebagai sarana konseling bagi anak yang agresif. Peningkatan empati menjadi perubahan kualitas yang unik. Proses diskusi literatur yang berfokus pada karakeristik emosi dan pemahaman motif perilaku dapat menumbuhkan model interaksi yang saling berempati.

Selain perubahan pada tingkat perilaku agresinya, perkembangan juga terlihat pada keaktifan partisipan dalam kelompok. Pada sesi awal intervensi, perlu dibuat peraturan bahwa group leader akan menunjuk salah satu partisipan untuk menangapi pertanyaan atau bercerita karena adanya partisipan yang bersikap pasif (seperti D dan W). Seluruh partisipan awalnya juga terlihat mengalami kesulitan untuk terbuka dan bercerita pengalamannya untuk melakukan eksporasi diri, namun partisipan terlihat semakin aktif serta semakin berani jujur dan terbuka sejalan dengan proses intervensi. Hal tersebut dapat terjadi karena bibliotherapy juga berdampak pada penurunan tingkat kecemasan partisipan. Akhirnya perkembangan tersebut juga dapat membantu perubahan yang positif pada partisipan sebagai hasil dari intervensi. Hal tersebut juga ditemukan sebagai hasil penelitian dari Shechtman (2000) bahwa intervensi bibliotherapy dapat menjadi sarana pembelajaran eksperimental yang memberikan kesempatan untuk mengekspresikan emosi, mengembangkan self-awareness, dan kemampuan sosial. Selain itu juga terjadi penurunan keinginan untuk menarik diri, kecemasa, perilaku depresi, masalah sosial, dan masalah atensi sebagai tujuan dari program intervensi.

\section{KESIMPULAN DAN SARAN}

Berdasarkan hasil penelitian dapat disimpulkan bahwa bibliotherapy dapat diterapkan dan efektif digunakan untuk menurunkan tingkat perilaku agresi pada remaja di LPKA X. Efektivitas bibliotherapy untuk menurunkan tingkat perilaku agresi pada remaja dapat dilihat dari hasil perbandingan pre-test dan post-test. Hasil observasi selama proses intervensi sesi tiga sampai enam juga dapat menunjukkan adanya perubahan perilaku agresi partisipan. Hal tersebut terlihat pada partisipan $\mathrm{R}, \mathrm{RR}, \mathrm{A}$, dan $\mathrm{P}$ yang awalnya cenderung berperilaku agresi (mengejek, meremehkan, atau merendahkan) terhadap partisipan lain hingga membuat partisipan tersebut merasa tidak senang atau terjadi keributan. Setelah menjalani proses intervensi, RR terlihat tidak 
membalas perilaku temannya yang negatif sedangkan partisipan lainnya juga tidak kembali menunjukkan perilaku agresi pada sesi intervensi terakhir. Bibliotherapy juga efektif untuk memberikan pemahaman kepada partisipan mengenai emosi marah yang mempengaruhi perilaku agresi, perlunya menggunakan kekuatan dengan benar, menumbuhkan empati, dan memperhatikan kontrol diri.

Saran untuk Partisipan. Untuk memaintain perilakunya (mempertahankan hasil intervensi), partisipan disarankan untuk berusaha menyalurkan dorongan agresinya dalam bentuk lain sebagai penyaluran emosinya. Bentuk aktivitas atau kegiatan yang dapat dilakukan partisipan untuk menyalurkan dorongan agresinya seperti melakukan olahraga berlari, bermain sepak bola, bermain basket, bernyanyi, atau aktivitas lainnya. Partisipan juga dapat terlibat untuk membantu mengurus keperluan di dapur atau mushola, sehingga kesibukan tersebut mengalihkan dorongan partisipan untuk berperilaku agresi. Berikutnya partisipan juga perlu untuk melatih kemampuan mengontrol diri.Untuk meningkatkan kemampuan self-control, partisipan dapat disarankan untuk terbuka atau bercerita mengenai masalahnya supaya partisipan dapat mengontrol dirinya dari timbal balik positif yang diterima. Partisipan juga dapat mempelajari norma yang berlaku di masyarakat dan lebih memahami ilmu agama seperti mengikuti pengajian dengan baik.

Untuk meningkatkan kepercayaan diri, partisipan disarankan untuk berani terlibat dapat kegiatan-kegiatan yang mungkin dilakukan pihak LPKA X seperti mengikuti kegiatan lomba (seperti perlombaan menggambar, bernyanyi, menulis cerita, ataupun kegiatan olahraga). Dalam kegiatan tersebut, partisipan diharapkan dapat berekspresi atau menunjukkan kemampuan dirinya sehingga individu lain akan memberikan timbal balik yang positif. Timbal balik atau apresiasi yang diterima dapat semakin meningkatkan kepercayaan diri partisipan karena partisipan semakin menyadari kemampuan positif yang ia miliki.

Saran untuk LPKA $\mathrm{X}$. Untuk semakin menurunkan tingkat perilaku agresi para andikpas, petugas bagian pengembangan atau pendidikan di LPKA $\mathrm{X}$ dapat menerapkan cara yang serupa dengan bibliotherapy (setelah melihat efektivitas bibliotherapy untuk menurunkan tingkat perilaku agresi remaja). Para petugas dapat memberikan waktu khusus setiap minggunya untuk memberikan materi mengenai perilaku agresi kepada para andikpas dengan bantuan media literatur cerita, film, dan gambar. Petugas dapat mengajak para andikpas untuk mengevaluasi perilaku tokoh dalam literatur tersebut dan melakukan refleksi diri mengenai perilakunya. Hal tersebut dapat membantu petugas memberikan pemahaman kepada andikpas mengenai perilaku yang sesuai dan perlu untuk ditampilkan (dapat juga menambah pengetahuan moral).

Untuk mengontrol perilaku para andikpas, petugas di LPKA X diharapkan dapat meluangkan waktu untuk mengajak para andikpas berbicara dan bercerita bersama mengenai masalah ataupun pemikiran andikpas saat itu. Kesempatan bercerita yang diberikan kepada para andikpas sebagai individu remaja juga dapat membantu para andikpas semakin memahami kondisi dirinya (dengan bantuan timbal balik positif). Para andikpas juga dapat menyampaikan kondisi emosinya saat itu, sehingga tidak dilampiaskan melalui perilaku negatif. Kepercayaan dan terbukaan selama melakukan interaksi sosial juga dapat melatih kepekaan emosional dan kemampuan adaptasi para andikpas dengan lingkungannya.

Untuk meningkatkan kepercayaan diri andikpas, petugas LPKA X dapat membantu para andikpas menyalurkan dan mengembangkan kemampuan yang dimilikinya. Petugas dapat membuat acara rutin (seperti perlombaan menggambar, bernyanyi, menulis cerita, ataupun kegiatan olahraga) untuk memberikan kesempatan kepada para andikpas menunjukkan 
kemampuan dirinya. Ketika para andikpas diberikan kesempatan tersebut, tingkat kepercayaan diri andikpas juga akan semakin meningkat karena ia dapat semakin memahami kemampuan yang dimiliki. Kepercayaan diri para andikpas dengan kemampuannya dapat menjadi modal keberhasilan para andikpas untuk berkarya ketika sudah keluar dari penjara.

\section{Ucapan Terima Kasih (Acknowledgement)}

Ucapan terima kasih kepada seluruh partisipan dalam penelitian ini yang telah bersedia untuk meluangkan waktu, bekerja sama, dan kesediaanya untuk terbuka dalam proses pengumpulan data dan mengikuti intervensi kelompok. Peneliti juga berterima kasih kepada LPKA $X$ yang telah memberikan izin kepada peneliti untuk dapat melakukan proses penelitian dan intervensi kelompok selama beberapa pekan. Kesempatan yang diberikan LPKA X sangat mendukung peneliti atas kelancaran terlaksananya penelitian ini.

\section{REFERENSI}

Baron, R. A., \& Branscombe, N. R. (2012). Social psychology (13th ed.). America, US: Pearson Education, Inc.

Buss, A. H. (1961). The psychology of aggression. Hoboken, NJ, US: John Wiley \& Sons Inc. DOI: $10.1037 / 11160-000$

Buss, A. H., \& Perry, M. (1992). The aggression questionnaire. Journal of Personality and Social Psychology, 63 (3), 452-459

Lova, C. (15 November, 2018). Polisi tangkap 2 begal yang tusuk korban hingga kritis di GDC Depok. Kompas.com. Diunduh dari https://megapolitan.kompas.com/

Newman, K. (2015). Bibliotherapy as an intervention for aggressive elementary children. Tesis. Brigham Young University.

Papalia, D. E., \& Feldman, R. D. (2012). Experience human development (12th ed.). America, NY: McGraw-Hill Companies.

Shechtman, Z. (2000). An innovative intervention for treatment of child and adolescent aggression: An outcome study. Psychology in the Schools, 37 (2), 157-167. Doi: 10.1002/(sici)1520-6807(200003)37:2<157::aid-pits7>3.0.co;2-g

Shechtman, Z. (2006). The contribution of bibliotherapy to the counseling of aggressive boys. Psychotherapy Research, 16 (5), 645-651. Doi:10.1080/10503300600591312

Shechtman, Z. (2009). Treating child and adolescent aggression through bibliotherapy. New York, NY: Springer Science+Bussiness Media

Zuraya, N. (21 Juli, 2017). ICJR: Jumlah tahanan anak di Indonesia meningkat pesat. Republika.com. Diunduh dari https://www.republika.co.id/ 